\title{
STRIX NEBULOSA.
}

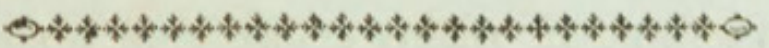

\section{CHARACTER GENERICUS.}

Roftrum aduncum. (abfque cera.)

Nares pennis fetaceis recumbentibus obtectæ.

Caput grande: auribus oculifque magnis.

Lingua bifida.

$$
\begin{aligned}
& \text { Lin. Syf. Nat. p. } 131 . \\
& \text { Ord. Accipitres. }
\end{aligned}
$$

CHARACTER SPECIFICUS, ËC.

STRIX fufco albidoque tranfverfim fafciata, abdomine albo maculis oblongis ferrugineis.

Penn. Zool. Arct. p. 234.

Act Angl. vol. 62. p. 424 .

Lath. Synopf. p. 133 .

Hæc avis inter majores fui generis exftat, quamvis aliis fpeciebus magnitudine impar. Specimen a Doctore Forster in Actis Anglicis defcriptum pondere erat librarum trium, longitudine fedecim unciarum, latitudine quatuor pedum. Tota avis fufco albidoque colore tranfverfim fafciata eft, fafciis verfus caput minoribus et numerofioribus. In imo ventre et fuper latera funt maculæ variæ longitudinales, magnæ, ferrugineo-fufcæ. Pallidæ quæ oculos cingunt plumæ, M

Atriis 
ftriis concentricis fufcis leviter notantur. Super remiges alarum et caudam fafciæ alternatim albæ fufcæque majores funt, et magis confpicuæ quam in aliis partibus. Colores totius avis funt molles et eleganter difpofiti. Sinum Hudfoni in America Septentrionali inhabitat hxc avis. 


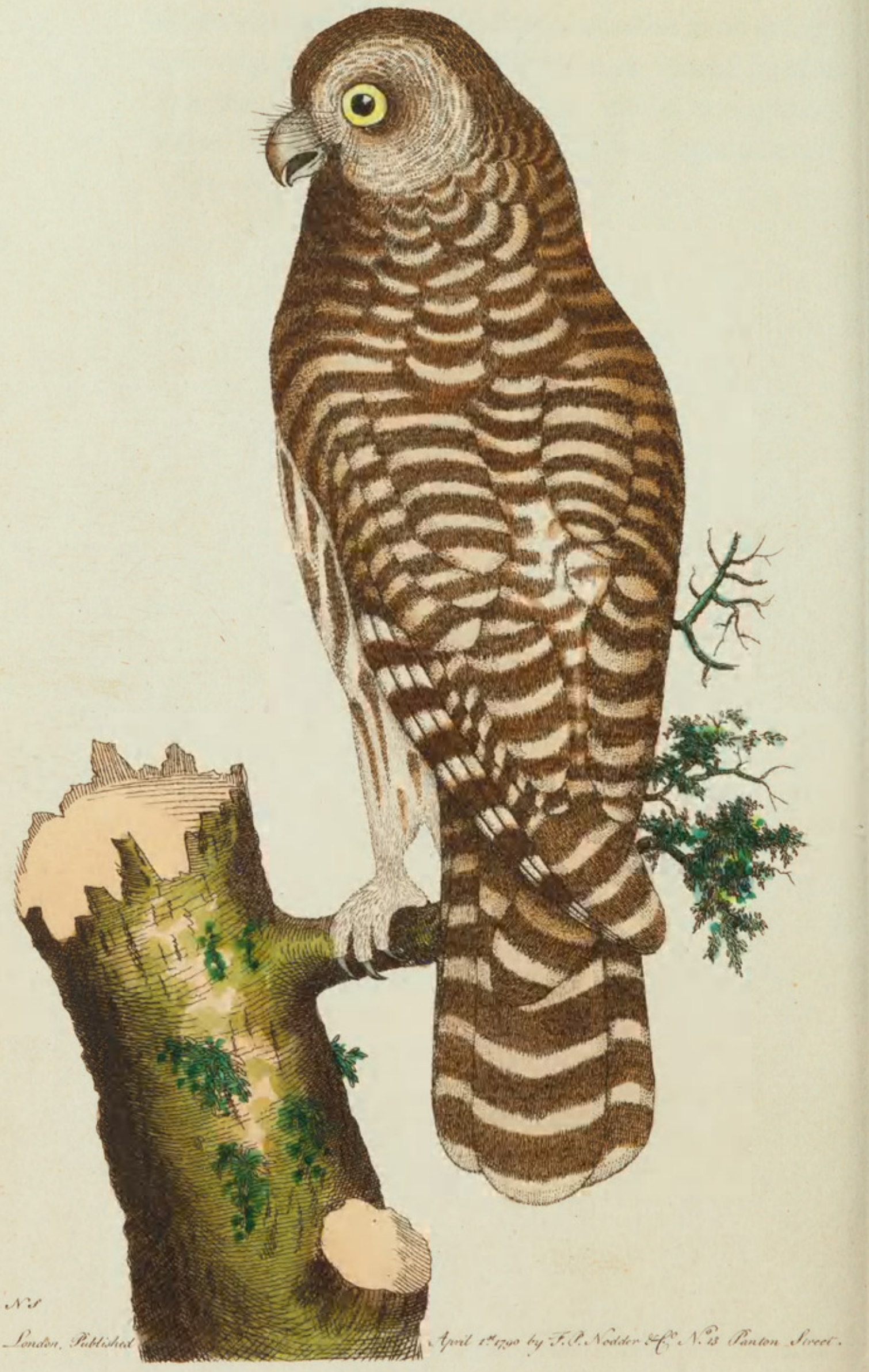


T H E

\section{L O U D E D O W L.}

-

GENERIC CHARACTER.

Bill crooked (not furnifhed with a cere.)

Noffrils covered with recumbent brifly feathers. Head large: Ears and Eyes largé.

Tongue bifid.

$$
\text { Lin. Syft. Nat.-Accipitres. }
$$

SPECIFIC CHARACTER, ङंC.

OWL tranfverfly fafciated with brown and whitifh, the belly white with oblong ferruginous fpots.

\section{BARRED OWL.}

Pennant. Arct. Zool. p. 234.

Lath. Synops. p. 133.

This is one of the larger fpecies of Owls, though inferior in fize to fome others of the genus. A fpecimen defcribed by Dr. Forster in the Philofophical Tranfactions weighed three pounds, and was in length fixteen inches, and in breadth, when extended, four feet. The whole bird is tranfverfly barred with brown and whitifh; the bars being fmalleft, and moft nume- 
rous towards the head. On the lower part of the belly, and on the fides, are fome large longitudinal marks of ferruginous brown. The feathers furrounding the eyes are of a pale colour, lightly marked with concentric ftriæ of brownifh. On the long feathers of the wings and tail, the alternate bars of brown and white are larger and more confpicuous than on the other parts. The colours on the whole bird are foft, and very elegantly difpofed. It is a native of Hudfon's Bay. 


\section{$2 \mathrm{BHL}$ Biodiversity Heritage Library}

Shaw, George. 1789. "The Clouded Owl, Strix nebulosa [PI. 25]." The Naturalist's Miscellany 1(V), https://doi.org/10.5962/p.310678.

View This Item Online: https://www.biodiversitylibrary.org/item/281460

DOI: https://doi.org/10.5962/p.310678

Permalink: https://www.biodiversitylibrary.org/partpdf/310678

\section{Holding Institution}

Museums Victoria

\section{Sponsored by}

Atlas of Living Australia

\section{Copyright \& Reuse}

Copyright Status: Public domain. The BHL considers that this work is no longer under copyright protection.

This document was created from content at the Biodiversity Heritage Library, the world's largest open access digital library for biodiversity literature and archives. Visit BHL at https://www.biodiversitylibrary.org. 